\title{
PEMANFAATAN TEKNOLOGI INFORMASI DAN KOMPUTER DALAM MENINGKATKAN KUALITAS GURU SDN TUGU 1 CIMANGGIS KOTA DEPOK JAWA BARAT
}

\author{
Sri Mardiyati ${ }^{*}$, Lusi Ariyani ${ }^{2}$, Wahyu Utama ${ }^{3}$, Firdaus Budhi Saputro ${ }^{4}$ \\ ${ }^{12}$ Teknik Informatika Universitas Indraprasta PGRI \\ ${ }^{34}$ Pendidikan Ekonomi Universitas Indraprasta PGRI \\ *Korespondensi: srimardiyati05@gmail.com
}

\begin{abstract}
ABSTRAK. Komputer adalah alat elektronik yang terdiri dari rangkaian berbagai komponen yang saling terhubung sehingga membentuk suatu sistem kerja. Sistem didalam komputer tersebut dapat melakukan pekerjaan secara otomatis berdasarkan program yang diperintahkan kepadanya sehingga mampu menghasilkan informasi berdasarkan data dan progam yang ada. Salah satu program komputer yang sering digunakan adalah Microsoft Office. Dari hasil observasi awal yang dapat dilakukan tim pengusul sebelum dilaksanakan tindakan Pemanfaatan Teknologi Informasi dan Ilmu Komputer, diketahui bahwa tidak semua guru dan staf menguasai TIK. Kompetensi guru di bidang Teknologi Informasi dan Ilmu Komputer perlu dioptimalkan, baik dari segi pemahaman materi maupun dari segi ketrampilan praktek. Oleh karena itu diperlukan pemahaman materi dan ketrampilan praktek Microsoft office. Dengan adanya pelatihan penggunaan aplikasi Ms. Power Point ini diharapkan dapat menjadi solusi dari masalah yang dihadapi untuk membantu Mitra yaitu untuk dapat membuat suatu file presentasi yang lebih menarik dan atraktif sehingga informasi, materi dan pesan yang disampaikan pada saat penyuluhan maupun pengajaran sehingga dapat lebih mudah dimengerti oleh para guru SDN Tugu 1 Cimanggis Kota Depok
\end{abstract}

Kata kunci: Microsoft Office, Powerpoint, Pelatihan, SDN Tugu 1 Cimanggis

ABSTRACT. A computer is an electronic device that consists of a series of various components that are interconnected to form a working system. The system in the computer can do work automatically based on the program ordered to it so that it is able to produce information based on existing data and programs. One of the computer programs that are often used is Microsoft Office. From the results of initial observations that the proposing team could do before implementing the use of Information Technology and Computer Science, it is known that not all teachers and staff master ICT. Teacher competence in the field of Information Technology and Computer Science needs to be optimized, both in terms of understanding the material and in terms of practical skills. Therefore, it is necessary to understand the material and practice Microsoft office skills. With the training on the use of the Ms. This Power Point is expected to be a solution to the problems faced to help Partners, namely to be able to create a presentation file that is more attractive and attractive so that information, materials and messages conveyed during counseling and teaching can be more easily understood by Tugu 1 Elementary School teachers. Cimanggis Depok City

Keywords: Microsoft Office, Powerpoint, Training, SDN Tugu 1 Cimanggis

\section{PENDAHULUAN}

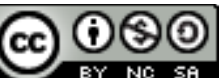

This work is licensed under a Creative Commons Attribution-NonCommercial-ShareAlike 4.0

International License. 
Perkembangan Ilmu Pengetahuan dan Teknologi saat ini terus maju dan berkembang dengan pesatnya. Hal ini dapat dirasakan manfaatnya diberbagai bidang kehidupan manusia, salah satu wujud nyata dari hasil Ilmu Pengetahuan dan Teknologi dibidang informasi adalah teknologi komputer. Hampir diseluruh sektor menggunakan komputer sebagai alat untuk membantu pekerjaan. Komputer adalah alat elektronik yang terdiri dari rangkaian berbagai komponen yang saling terhubung sehingga membentuk suatu sistem kerja. Sistem didalam komputer tersebut dapat melakukan pekerjaan secara otomatis berdasarkan program yang diperintahkan kepadanya sehingga mampu menghasilkan informasi berdasarkan data dan progam yang ada. Salah satu program komputer yang sering digunakan adalah Microsoft Office.

Sekolah Dasar Negeri Tugu 1 yang berada pada wilayah kota Depok. SDN 1 Tugu berlokasi di Jalan Ponpes Nurul Huda, Pasirgunung Selatan Kec. Cimanggis Kota Depok Jawa Barat

Teknologi Informasi dan Komunikasi sudah diperkenalkan di semua jenjang Pendidikan termasuk sekolah dasar. Menurut (Warsita, 2008) [1] teknologi informasi adalah sarana dan prasarana (hardware, software, useware) sistem dan metode untuk memperoleh, mengirimkan, mengolah, menafsirkan, menyimpan, mengorganisasikan, dan menggunakan data secara bermakna.

Kurikulum Pendidikan yang memasukan TIK sebagai satu mata pelajaran, merupakan bukti bahwa kemajuan teknologi mempengaruhi Pendidikan di negara kita. Jalur pendidikan formal berpotensi dan bernilai strategis untuk menyelenggarakan pendidikan dan latihan di bidang TIK yang idealnya dimulai sejak dini. Hal ini mengisyaratkan pentingnya bagi guru-guru dalam memanfaatkan sarana teknologi informasi dan komunikasi khususnya komputer yang bermanfaat sebagai bekal kemampuan dasar dan memecahkan masalah yang akan dihadapi dalam kehidupannya kelak. Oleh karena itu para guru dituntut untuk meningkat kualitas pengajaran dengan lebih optimal memahami dan menguasai teknologi informasi dan komunikasi.

\section{Permasalahan}

Dari hasil observasi awal yang dapat dilakukan tim pengusul sebelum dilaksanakan tindakan Pemanfaatan Teknologi Informasi dan Ilmu Komputer, diketahui bahwa tidak semua guru dan staf menguasai TIK. Kompetensi guru di bidang Teknologi Informasi dan Ilmu Komputer perlu dioptimalkan, baik dari segi pemahaman materi maupun dari segi ketrampilan praktek. Oleh karena itu diperlukan pemahaman materi dan ketrampilan praktek Microsoft office. [2]

Dengan pengembangan bidang TIK dalam hal pemahaman materi maupun dari segi ketrampilan praktek, memberikan bekal kepada guru dan staf dalam menyongsong masa depan yang diperkirakan dan sudah pasti akan lebih banyak lagi penggunaan teknologi informasi dalam kehidupan sehari-hari.

\section{SOLUSI DAN TARGET LUARAN}

Dengan melihat permasalahan yang ada, solusi yang akan diberikan dari kegiatan IbM terhadap permasalahan mitra adalah memberikan pelatihan Pemanfaatan Teknologi Informasi dan Komunikasi Bagi guru dan staf Taman Kanak - kanak (TK) Bhayangkari 60, Kelapadua, Cimanggis, Kota Depok. Diharapkan Mitra mendapatkan Peningkatan kualitas pendidikan sejalan dengan optimalisasi kompetensi guru dan staf sekolah akan Teknologi Informasi dan Komunikasi.

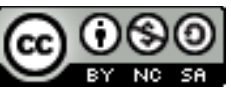

This work is licensed under a Creative Commons Attribution-NonCommercial-ShareAlike 4.0 International License. 


\section{A. Target}

1. Memberikan ketrampilan komputer bagi guru dan staf Gugus Inovatif Taman Kanak-kanak Kemala Bhayangkari Kelapa Dua Cimanggis Kota Depok yaitu Microsoft Office dan Aplikasi Paint

2. Peningkatan mutu dan kompetensi bagi guru Sekolah Dasar Negeri Tugu 1 Cimanggis Kota Depok Jawa Barat.

3. Peningkatan pemahaman bagi guru Sekolah Dasar Negeri Tugu 1 Cimanggis Kota Depok Jawa Barat akan manfaat Teknologi Informasi dan Komunikasi

\section{B. Luaran}

Luaran yang hendak didapat dari kegiatan IbM adalah sebagai berikut:

1. Jasa Pelatihan Pemanfaatan Teknologi Informasi dan Komunikasi, yaitu ketrampilan komputer menggunakan Microsoft Word dan Aplikasi Paint

2. Modul ketrampilan komputer yaitu menggunakan Microsoft word dan Aplikasi Paint yang dapat dipakai secara umum oleh bagi guru SD

\section{METODE PELAKSANAAN}

Kegiatan IbM ini merupakan Optimalisasi pemanfaatan teknologi informasi dan komunikasi dengan memberikan pelatihan Microsoft Powerpoint dan Aplikasi Paint kepada guru Sekolah Dasar Negri Tugu 1 Kelapa Dua Cimanggis Kota Depok . Berikut tahapan kegiatan IbM yang akan dilakukan :

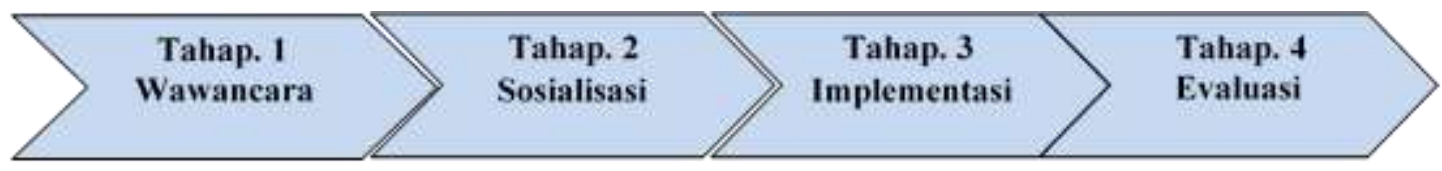

1. Tahap 1

Melakukan wawancara secara lisan kepada stack holder dalam hal ini kepala Sekolah SDN Tugu 1 Kelapa Dua Cimanggis Kota Depok untuk menentukan Aplikasi komputer yang perlu dipelajari oleh guru di sekolah.

2. Tahap 2

Sosialisasi bagi guru dan staf sekolah akan manfaat dari pelatihan aplikasi komputer dan kegiatan IbM untuk memastikan bahwa stack holder telah mengetahui keberadaan dan manfaat pelatihan Aplikasi komputer.

3. Tahap 3

Implementasi pelatihan Aplikasi komputer dalam dalam meningkatan kualitas guru dan staf sekolah dalam menggunakan Microsoft Powerpoint dan Aplikasi Paint

4. Tahap 4

Melakukan evaluasi keseluruhan proses kegiatan IbM.

\section{Metode Pendekatan}

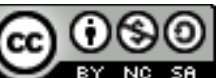

This work is licensed under a Creative Commons Attribution-NonCommercial-ShareAlike 4.0

International License. 
TRIDHARMADIMAS: Jurnal Pengabdian Kepada Masyarakat Jayakarta

http://journal.stmikjayakarta.ac.id/index.php/tridharmadimas

EmaiL: info@stmik.jayakarta.ac.id , tridharmadimas.jayakarta@gmail.com DOI : 10.52362/tridharmadimas.v1i2.596/halaman : 56-62

E-ISSN: 2798-8295 (Online), P-ISSN: 2798-8554 (Print) Vol. 1, No.2, Desember 2021

Metode pendekatan kegiatan IbM adalah dengan melakukan wawancara kepada kepala sekolah untuk mengetahui materi Teknologi Informasi dan Komunikasi guna mendapatkan gambaran kebutuhan mitra sehingga produk yang diciptakan dapat memberikan manfaat dan solusi yang tepat.

Partisipasi mitra dalam pelaksanaan kegiatan IbM :

1. Guna tercapainya tujuan dari kegiatan ini diharapkan mitra dapat memberikan informasi yang dianggap mampu mendukung kegiatan IbM berkenaan dengan kegiatan pembelajaran/ pelatihan.

2. Melakukan pengujian terhadap produk yang diciptakan.

3. Implementasi produk dalam kegiatan pembelajaran/ pelatihan.

\section{HASIL YANG DICAPAI}

\section{A. Kegiatan Persiapan Pengabdian Masyarakat}

Kegiatan pengabdian masyarakat dengan judul "Pemanfaatan Teknologi Informasi dan Komputer dalam Meningkakan Kualitas Guru Sekolah Dasar Negeri Tugu 1 Cimanggis Kota Depok Jawa Barat." akan dilaksanakan. Sebelumnya tim Abdimas melakukan beberapa persiapan, diantaranya menyiapkan materi, wawancara secara daring dan melakukan perijinan terhadap mitra untuk dapat melaksanakan Abdimas sesuai dengan kebutuhan mitra. Setelah mendapatkan perijinan dan mengetahui kebutuhan mitra, tim Abdimas menyusun modul pelatihan sebagai bahan ajar saat melakukan pelatihan Microsoft Powerpoint dan Aplikasi Paintl, dan modul tersebut dibagikan kepada guru-guru Sekolah Dasar Negeri Tugu 1 Cimanggis kota Depok.. Kegiatan dilanjutkan dengan mempersiapkan peralatan yang dibutuhkan untuk menunjang kegiatan Abdimas yaitu menyiapkan Laptop dan Proyektor sebagai media yang penting dalam kegiatan Abdimas, dan menyiapkan softfile materi yang digunakan secara daring dengan berinteraksi melalui fasilitas WhatsApp Group (WAG).

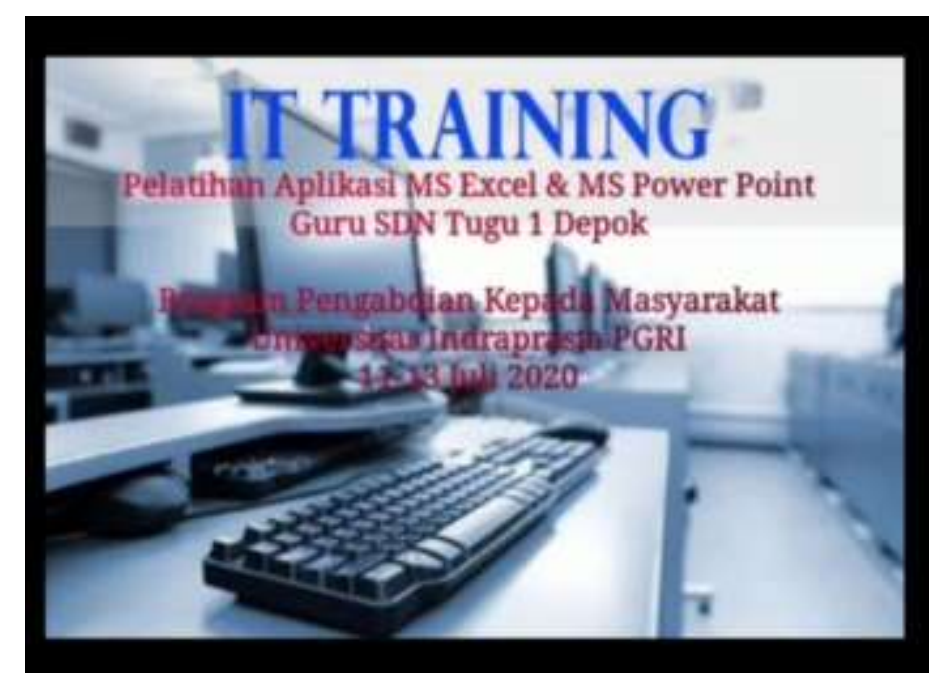

Gambar 1. Persiapan Pelatihan

\section{B. Realisasi Kegiatan}

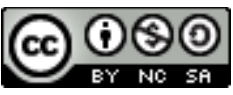

This work is licensed under a Creative Commons Attribution-NonCommercial-ShareAlike 4.0 International License. 
Komputer merupakan teknologi yang terus berkembang dan sangat membantu dalam kehidupan. Salah satu program penting yang wajib dimiliki dan dikuasai oleh seorang pengguna komputer adalah Microsoft Office. Program ini dapat membantu untuk mengerjakan pekerjaan mengolah data dengan lebih mudah. Di dalam Microsoft Office ada banyak jenis program yang bisa digunakan, misalnya Microsoft Powerpoint dan Aplikasi Paint. Pada kegiatan ini guru-guru diberikan pelatihan mengenai penggunaan Microsoft Powerpoint dan Aplikasi Paint.. Saat pelatihan Microsoft Powerpoint dan Aplikasi Paint., Guru-guru diberikan penjelasan mengenai bagaimana berkreasi membuat tampilan slide untuk mengajar dikelas lebih bagus dan inovatif. [3]

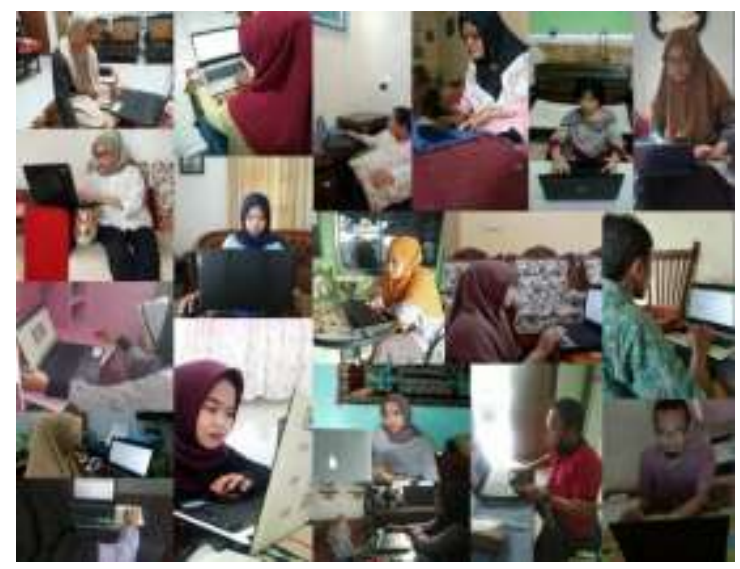

Gambar 2. Realisasi Kegiatan

\section{Pelaksanaan Kegiatan}

Pada pelaksaan kegiatan tim memberikan pengetahuan dasar tentang pengetahuan dasar Microsoft Powerpoint dan Aplikasi Paint kemudian melakukan implementasi penggunaan Microsoft Powerpoint dan Aplikasi Paint kepada guru-guru SDN Tugu 1 Cimanggis Kota Depok. (Permana, 2013) [4] Tim Pelaksana memberikan contoh penggunaan Microsoft Powerpoint dan Aplikasi Paint secara Daring melalui whatsApp Group (WAG) seperti pembuatan dokumen, insert picture, berkreasi menampilkan tampilan yang penuh dengan inovatif. Dilanjutkan dengan penggunaan Aplikasi Paint seperti Insert Gambar, mengedit grafik. Para peserta pelatihan mencoba mempraktekan materi yang sudah diberikan dengan di dampingi oleh tim pelaksana. Pemberian materi dijelaskan langkah demi langkah, diikuti atau dipraktekan langsung secara Daring atau Online oleh peserta pelatihan. Pelatihan berjalan dengan baik sampai dengan langkah pembuatan aplikasi yang terakhir. Kemudian pada sesi berikutnya para peserta pelatihan diminta membuat aplikasi sendiri sesuai dengan kemampuang masing-masing dan hasilnya dikirimkan melalui email tim yg diberikan sebeelumnya. Pada sesi pembuatan aplikasi sendiri, tidak semua peserta bisa menyelesaikan dengan sempurna. Hanya beberapa peserta yang dapat menyelesaikan dengan baik.

\section{Hasil Pelatihan Keterampilan}

This work is licensed under a Creative Commons Attribution-NonCommercial-ShareAlike 4.0 International License. 
EmaiL: info@stmik.jayakarta.ac.id , tridharmadimas.jayakarta@gmail.com DOI : 10.52362/tridharmadimas.v1i2.596/halaman : 56-62

E-ISSN: 2798-8295 (Online), P-ISSN: 2798-8554 (Print) Vol. 1, No.2, Desember 2021

Tim abdimas terdiri dari empat orang dari Universitas Indraprasta PGRI yang terdiri dari ketua dan tiga anggota. Dari pemaparan realisasi kegiatan pada pembahasan sebelumnya, adapun hasil yang diperoleh dari kegiatan ini yaitu Guru-guru Sekolah Dasar Negeri Tugu 1 Cimanggis kota Depok mendapat pengetahuan tentang penggunaan Microsoft Powerpoint dan Aplikasi Paint., dan dapat dipraktekkan secara langsung saat kegiatan pengabdian masyarakat. Dengan memberikan bebrapa latihan yang dikerjakan secara online arat secara Daring kemudian Hasil tersebut peserta mengirimkan melalui email.

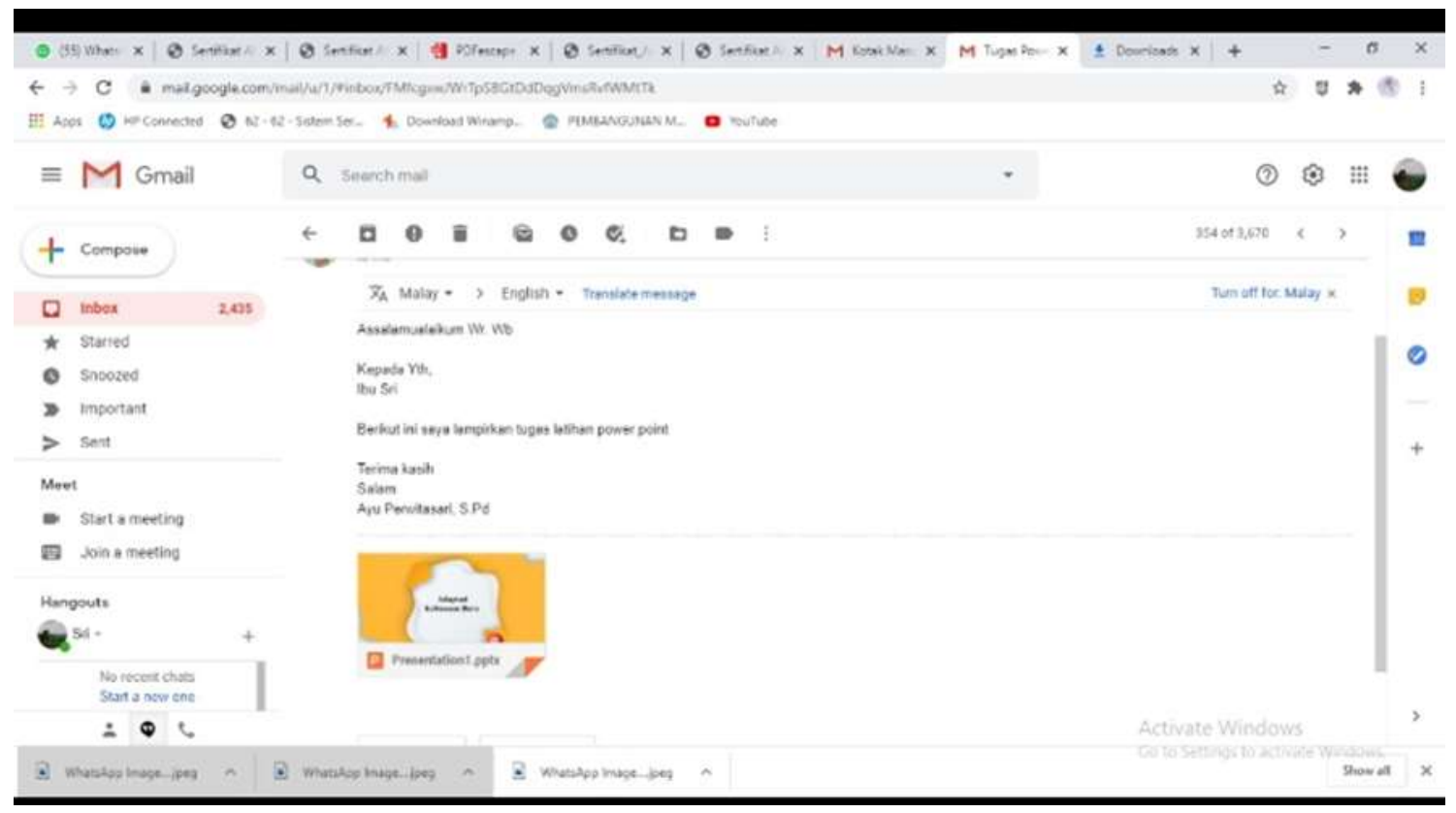

Gambar 4. Hasil Pelatihan dan Ketrampilan

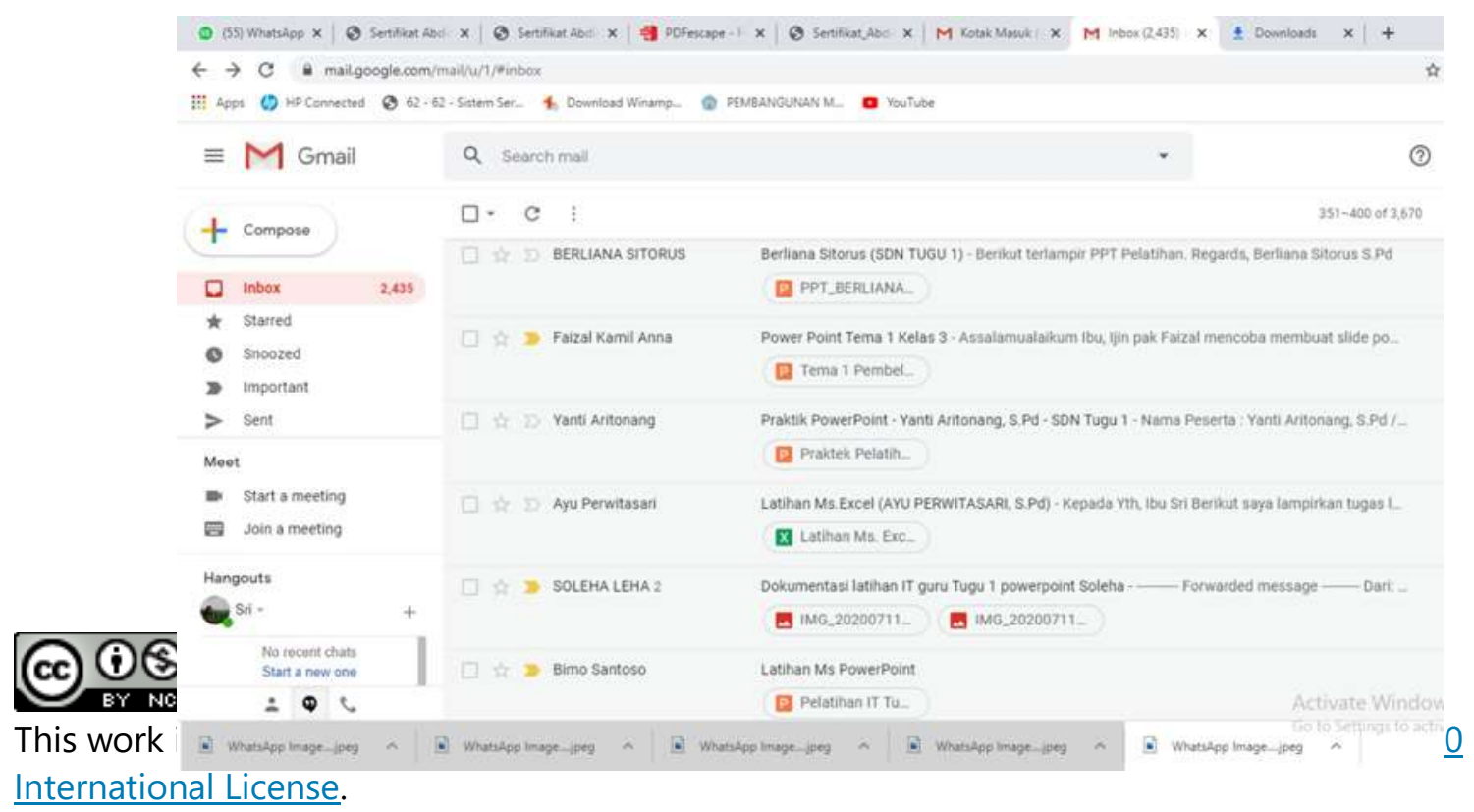


TRIDHARMADIMAS: Jurnal Pengabdian Kepada Masyarakat Jayakarta

http://journal.stmikjayakarta.ac.id/index.php/tridharmadimas

EmaiL: info@stmik.jayakarta.ac.id , tridharmadimas.jayakarta@gmail.com

DOI : 10.52362/tridharmadimas.v1i2.596/halaman : 56-62

E-ISSN: 2798-8295 (Online), P-ISSN: 2798-8554 (Print) Vol. 1, No.2, Desember 2021

Gambar 5. Hasil Pelatihan dan Ketrampilan

\section{KESIMPULAN}

Pada Kegiatan pengabdian masyarakat yang dilaksanakan secara Daring atau Online pada guru-guru Sekolah Dasar Negeri Tugu 1 Cimanggis kota Depok dapat dilaksanakan dengan baik. Para peserta sangat antusias dalam melaksanakan kegiatan pengabdian masyarakat yang diberikan oleh tim. Dengan kegiatan pelatihan ini, para guru dan staf dapat menggunakan dan meningkatkan ketrampilan dalam menggunakan aplikasi Microsoft Powerpoint dan Aplikasi Paint Luaran pengabdian masyarakat adalah peningkatan ketrampilan para guru dan staf dalam menggunakan Microsoft Office terutama Microsoft Powerpoint dan Aplikasi Paint

\section{DAFTAR PUSTAKA}

[1] Warsita, B. (2008). Teknologi pembelajaran landasan dan aplikasinya Jakarta: Rineka

[2] Hartoko, A. (2014). Kupas Tuntas Microsoft Office 2010. Elex Media Komputindo.

[3] Hasym, M. (2009). Buku Pintar Microsoft Office. Niaga Swadaya.

[4] Permana, B. (2013). 36 Jam Belajar Komputer Microsoft Office 2007. Elex Media Komputindo. 